OPEN ACCESS

Identifying Contact Resistances in High-Voltage Cathodes by Impedance Spectroscopy

To cite this article: Daniel Pritzl et al 2019 J. Electrochem. Soc. 166 A582

View the article online for updates and enhancements. 


\title{
Identifying Contact Resistances in High-Voltage Cathodes by Impedance Spectroscopy
}

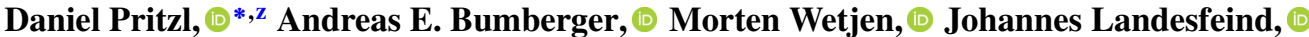 \\ Sophie Solchenbach, (1)* and Hubert A. Gasteiger**
}

Chair of Technical Electrochemistry, Department of Chemistry and Catalysis Research Center, Technical University of Munich, Munich, Germany

\begin{abstract}
$\mathrm{LiNi}_{0.5} \mathrm{Mn}_{1.5} \mathrm{O}_{4}$ (LNMO) cathodes cycled versus a graphite anode at elevated temperatures usually show severe capacity fading upon extended charge/discharge cycling. In the literature, the impedance increase at the cathode is often related to the formation of a so-called cathode/electrolyte interphase (CEI) and is presented as one of the possible failure mechanisms. In this study, we show that the main reason for the increasing cathode impedance is a contact resistance $\left(R_{\text {Cont. }}\right)$ between the aluminum current collector and the cathode electrode rather than a surface film resistance $\left(R_{\mathrm{CEI}}\right)$. First evidence is presented by temperature-dependent impedance measurements and external compression of the electrode stack in the cell, which suggest an electronic nature of the commonly observed high-frequency semi-circle in a Nyquist plot. Further, by coating the LNMO cathode onto a glassy carbon disk, we demonstrate that the impedance increase arises from the interface between the cathode electrode and the aluminum current collector. Finally, we examine whether $R_{\text {Cont. }}$ correlates with the release of protic species (e.g., HF) formed upon electrolyte oxidation. This is done by cycling graphite/LFP cells in the absence/presence of deliberately added HF, showing that a contact resistance upon cycling only develops upon HF addition.

(C) The Author(s) 2019. Published by ECS. This is an open access article distributed under the terms of the Creative Commons Attribution Non-Commercial No Derivatives 4.0 License (CC BY-NC-ND, http://creativecommons.org/licenses/by-nc-nd/4.0/), which permits non-commercial reuse, distribution, and reproduction in any medium, provided the original work is not changed in any way and is properly cited. For permission for commercial reuse, please email: oa @ electrochem.org. [DOI: 10.1149/2.0451904jes]
\end{abstract}

(cc) BY-NC-ND

Manuscript submitted December 6, 2018; revised manuscript received February 4, 2019. Published February 21, 2019. This was Paper 111 presented at the National Harbor, Maryland Meeting of the Society, October 1-5, 2017.

Commercial Li-Ion batteries based on a graphite/LiCoO ${ }_{2}$ chemistry have reached their limits regarding energy density. ${ }^{1}$ In order to increase the energy density of Li-Ion batteries, either the capacity or the voltage of the cathode active materials (CAMs) has to be increased. Furthermore, cobalt is considered a supply-limited critical raw material ${ }^{2}$ and a significant fraction of cobalt is produced by hazardous artisanal mining in the Democratic Republic of Congo, ${ }^{3}$ so that a reduction/elimination of the cobalt content in CAMs is required. A promising cobalt-free cathode material which also fulfills the criterion of a high energy density ${ }^{4}$ is the so-called high-voltage spinel $\mathrm{LiNi}_{0.5} \mathrm{Mn}_{1.5} \mathrm{O}_{4}$ (LNMO). However, while graphite/LNMO cells have a reasonable cycle life at room temperature, they usually show severe capacity fading at elevated temperatures $\left(>40^{\circ} \mathrm{C}\right) .^{5,6}$ The reasons for the poor capacity retention are frequently related to: i) manganese dissolution from the LNMO cathode and its subsequent reduction on the surface of the graphite anode (often described as cross-talk phenomenon), which damages the solid-electrolyteinterphase (SEI) on the graphite anode and catalyzes further electrolyte decomposition, ${ }^{3,6-9}$ thereby resulting in a loss of active lithium; (ii) electrochemical electrolyte oxidation at the high LNMO cathode potential, ${ }^{10,11}$ which leads to the release of protic species (e.g., HF), ${ }^{12}$ often seen as a key driver for transition metal dissolution and concomitant SEI damage $;^{6,13}$ and, (iii) an increase of the full-cell impedance over cycling. ${ }^{6}$ Based on detailed impedance studies, the latter is often ascribed to an increase of the LNMO cathode impedance. ${ }^{14,15}$ For example, Aurbach et al. ${ }^{14}$ measured the impedance of the LNMO cathode versus a lithium wire reference electrode after cycling at elevated temperatures $\left(60^{\circ} \mathrm{C}\right)$, and observed both a high-frequency semicircle (apex frequency $\approx 1 \mathrm{kHz}$ ) and a low frequency semi-circle (apex frequency $\approx 100 \mathrm{mHz}$ ). They attributed the former to a surface film resistance (often referred to as cathode electrolyte interphase (CEI) resistance) and the latter to a charge-transfer resistance. Similarly, Duncan et al. ${ }^{15}$ used a lithium ring as reference electrode in order to monitor the impedance evolution of the LNMO cathode upon cycling. They observed the same impedance features as Aurbach et al., ${ }^{14}$ i.e., two semi-circles at high and low frequency, respectively, which

*Electrochemical Society Member
$* *$ Electrochemical Society Fellow.

${ }^{\mathrm{z}}$ E-mail: daniel.pritzl@tum.de they attributed to the surface chemistry of the LNMO cathode. As the semi-circle at high frequency could already be observed prior to applying current to the cell, the authors attributed it to the spontaneous formation of a surface layer on the LNMO particles once they get in contact with the electrolyte, analogous to the prior assignment of the high-frequency semi-circle to the CEI by Aurbach et al. ${ }^{14}$ Upon cycling, this feature gradually increased, which Duncan et al. tentatively ascribed to the growth of the CEI. ${ }^{15}$

In contrast to the above interpretation reached for graphite/LNMO cells, Gaberscek et al. ${ }^{16}$ assigned the high-frequency semi-circle in cathode impedance spectra observed for graphite $/ \mathrm{LiFePO}_{4}$ (LFP) cells to a contact resistance between the aluminum current collector and the LFP cathode electrode interface. This was based on impedance measurements in symmetric cells, where an LFP cathode was coated either onto pristine aluminum foil or onto an aluminum foil coated with a silver paste. When using the pristine aluminum foil, a high-frequency semi-circle was observed, while this feature was absent when using the silver paste coated aluminum foil. Further, they reported that the highfrequency semi-circle is independent of LFP particle size and LFP mass loading, and that it always has the same characteristic capacitance of $\approx 10^{1} \mu \mathrm{F} / \mathrm{cm}^{2}$. Since the typical double-layer capacitance is also on the order of $10^{1} \mu \mathrm{F} / \mathrm{cm}^{2},{ }^{17}$ this indicates that the interface which is responsible for this feature must have a very small surface area (on the order of a few $\mathrm{cm}^{2}$ ), from which the authors concluded that the highfrequency semi-circle in cathode impedance spectra originates from the interfacial resistance between the current collector and the cathode electrode rather than from the cathode active material interface with the electrolyte. Recently, similar results have been reported by our group for graphite/LNMO cells, ${ }^{18}$ where the impedance of an LNMO cathode was analyzed in-situ, utilizing a gold wire reference electrode $(\mathrm{GWRE})^{19}$ and a novel impedance procedure. Thereby, it was possible to deconvolute the contact resistance between the current collector and the cathode electrode $\left(R_{\text {Cont. }}\right)$ from the charge transfer resistance $\left(R_{\mathrm{CT}}\right)$ of the LNMO active material and from the pore resistance $\left(R_{\text {Pore }}\right)$ which is due to the ionic conduction resistance in the electrolyte phase within the porous electrode. We found that the main resistance increase over the course of extended charge/discharge cycling of graphite/LNMO cells at $40^{\circ} \mathrm{C}$ indeed comes from an increase of $R_{\text {Contact }}$ rather than from an increase in the LNMO charge-transfer or surface film (CEI) resistance that was suggested previously. ${ }^{14,15}$ 
Table I. Specifications of the different cathodes (LNMO and LFP) used in this study, i.e., composition, used current collector, and compression.

\begin{tabular}{|c|c|c|c|c|}
\hline electrode type & cathode active material (CAM) & Composition (CAM/carbon black/PVdF) & current collector & Compression (MPa) \\
\hline Type I & LNMO & $92 / 5 / 3$ & $\mathrm{Al}$ & 200 \\
\hline Type II & LNMO & $95 / 1.5 / 3.5$ & $\mathrm{Al}$ & 200 \\
\hline Type III & LNMO & $95 / 1.5 / 3.5$ & $\mathrm{Al}$ & 0 \\
\hline Type IV & LNMO & $95 / 1.5 / 3.5$ & glassy carbon & 0 \\
\hline Type V & LFP & $94 / 3 / 4$ & $\mathrm{Al}$ & 200 \\
\hline
\end{tabular}

While in this previous aging study on graphite/LNMO cells we identified the origin of the high-frequency semi-circle based on a simple estimate of the interfacial capacitance and the associated surface area, we here want to expand on our previous results and elucidate more clearly (i) the origin of the high-frequency semi-circle, (ii) its increase upon cycling, and, (iii) the parasitic reactions occurring in high-voltage Li-Ion cells which cause this resistance increase. In the first part, we investigate the influence of the carbon black content, the temperature, and the external cell compression on the cathode impedance spectra by using the GWRE to deconvolute the full-cell impedance spectra. From these experiments, we can show that the high-frequency semi-circle resistance is indeed an electronic contact resistance between the cathode electrode and the current collector $\left(R_{\text {Cont. }}\right)$, and that is not caused by an LNMO cathode surface film (CEI). In the second part, we will examine $R_{\text {Cont. }}$ with regard to the current collector material, comparing a standard aluminum current collector with a glassy carbon disk as model current collector. As conventional impedance analysis does not allow a precise quantification of $R_{\text {Cont. }}$, we will use the blocking electrode methodology ${ }^{18,20}$ to quantify the $R_{\text {Cont. }}$ evolution over extended cycling. Finally, we will investigate whether the $R_{\text {Cont. }}$ increase at the cathode is related to the formation of protic species (e.g., HF) upon electrolyte oxidation. This is done by comparing the impedance obtained with an LP57 electrolyte with our without intentionally added HF in graphite/LFP cells, where no electrochemical electrolyte oxidation and thus no formation of protic species should occur.

\section{Experimental}

Electrode preparation.- $\mathrm{LiNi}_{0.5} \mathrm{Mn}_{1.5} \mathrm{O}_{4}$ (LNMO) inks were prepared by mixing LNMO powder (BASF SE, Germany, with a BET area of $\approx 0.9 \mathrm{~m}^{2} / \mathrm{g}$ ), carbon black (Super C65, Timcal, Switzerland, with a BET area of $\approx 65 \mathrm{~m}^{2} / \mathrm{g}$ ), and polyvinylene difluoride (PVdF, Kynar) at mass ratios of 92/5/3 and 95/1.5/3.5 with NMP (N-methyl pyrrolidone, anhydrous, Sigma-Aldrich, Germany) at a solid content of $60 \%$ in a planetary mixer (Thinky Corp.) for $15 \mathrm{~min}$. These inks were then used to prepare the four different types of LNMO electrodes detailed in Table I. As a current collector, aluminum foil (MTI, $18 \mu \mathrm{m}$ ) was used for Type I, II, and III electrodes, while a glassy carbon disk (HTW, Germany, $500 \mu \mathrm{m}, 11 \mathrm{~mm}$ diameter) was used for type IV electrodes. For all electrodes, the ink was coated onto the current collector with a doctor blade coater and dried at $50^{\circ} \mathrm{C}$ in a convection oven for at least $3 \mathrm{~h}$. To coat the glassy carbon disk with the electrode ink, the disk was fitted into a copper-plate with a height of $500 \mu \mathrm{m}$ and a hole with a diameter of $11 \mathrm{~mm}$. All LNMO coatings had a loading of $\approx 14 \mathrm{mg}_{\mathrm{LNMO}} / \mathrm{cm}^{2}$, corresponding to a theoretical areal capacity of $\approx 2.0 \mathrm{mAh} / \mathrm{cm}^{2}$. From the coatings on aluminum foil, electrodes with a diameter of $11 \mathrm{~mm}\left(\equiv 0.95 \mathrm{~cm}^{2}\right)$ were punched out. A crosssectional SEM image of an LNMO coating (dried at $50^{\circ} \mathrm{C}$ for $3 \mathrm{~h}$ ) on a glassy carbon disk is shown in Figure 1. The Type I and II electrodes were compressed with a $\mathrm{KBr}$ press at $\approx 200 \mathrm{MPa}\left(2\right.$ tons $\left./ \mathrm{cm}^{2}\right)$ for $60 \mathrm{~s}$ to $\approx 30 \%$ porosity (determined by areal weight and thickness measurements, using the bulk density values for the electrode components), while Types III and IV electrodes were left uncompressed. Additionally, $\mathrm{LiFePO}_{4}$ (LFP) cathodes with a composition of 93/3/4 (LFP/carbon black/PVdF, by mass) and a theoretical areal capacity of $\approx 2.0 \mathrm{mAh} / \mathrm{cm}^{2}$ (corresponding to $\approx 11.5 \mathrm{mg} \mathrm{LFP}_{\mathrm{LP}} / \mathrm{cm}^{2}$ ) were prepared the same way as the LNMO Type I cathodes. Detailed information about the cathode coatings is summarized in Table I.
Graphite electrodes were prepared by mixing graphite (T311, SGL Carbon, Germany) and PVdF at a mass ratio of $95 / 5$ with NMP by applying the same coating process as for the cathodes, but coated onto a copper foil (MTI, $\approx 12 \mu \mathrm{m}$ ) and dried in a convection oven at $50^{\circ} \mathrm{C}$ for $3 \mathrm{~h}$. The loading of the graphite coatings was $\approx 6.3 \mathrm{mg}_{\text {graphite }} / \mathrm{cm}^{2}$, corresponding to a theoretical areal capacity of $\approx 2.3 \mathrm{mAh} / \mathrm{cm}^{2}$. The electrodes were punched out with a diameter of $11 \mathrm{~mm}$ and compressed at $\approx 50 \mathrm{MPa}\left(0.5\right.$ tons $\left./ \mathrm{cm}^{2}\right)$ for $60 \mathrm{~s}$ to a porosity of $\approx 30 \%$. Finally, all electrodes were dried under dynamic vacuum at $120^{\circ} \mathrm{C}$ for at least $12 \mathrm{~h}$ in a vacuum oven (Büchi, Switzerland) and then transferred into an argon-filled glove box (MBraun, Germany) without exposure to ambient atmosphere.

Battery testing.-Swagelok T-cells with a gold wire reference electrode $(\mathrm{GWRE})^{19}$ were assembled in a glove box filled with argon $\left(\mathrm{O}_{2}\right.$ and $\left.\mathrm{H}_{2} \mathrm{O}<0.1 \mathrm{ppm}\right)$ by sandwiching anode (graphite) and cathode (LNMO or LFP) between two glass fiber separators (11 mm diameter, $200 \mu \mathrm{m}$ thickness, glass microfiber \#691, VWR, Germany) and adding $60 \mu \mathrm{L}$ of standard LP57 electrolyte (1M LiPF 6 in EC/EMC (3:7 wt/wt), water content $<10 \mathrm{ppm}$, BASF SE, Germany). Battery cycling was carried out in a climate chamber $\left(25^{\circ} \mathrm{C}\right.$ or $40^{\circ} \mathrm{C}$, Binder, Germany) using a multi-channel battery cycler (Series 400 , Maccor, USA). The cycling protocol consisted of two formation cycles with $\mathrm{C} / 10(0.2$ $\left.\mathrm{mA} / \mathrm{cm}^{2}\right)$ at $25^{\circ} \mathrm{C}$, followed by 98 cycles with $1 \mathrm{C}\left(2.0 \mathrm{~mA} / \mathrm{cm}^{2}\right)$ at $40^{\circ} \mathrm{C}$. All cycles were conducted between 3.5 and $4.8 \mathrm{~V}$ cell voltage by applying a constant current constant voltage (CCCV) charge with a current limit of $\mathrm{C} / 20$ for the $\mathrm{CV}$ phase at $4.8 \mathrm{~V}$ and a constant current (CC) discharge procedure. The C-rate is defined by the theoretical capacity of LNMO $(\approx 140 \mathrm{mAh} / \mathrm{g})$ or LFP $(\approx 170 \mathrm{mAh} / \mathrm{g})$, i.e., $1 \mathrm{C}$ corresponds to $140 \mathrm{~mA} / \mathrm{g}\left(\approx 2.0 \mathrm{~mA} / \mathrm{cm}^{2}\right)$ for $\mathrm{LNMO}$ or $170 \mathrm{~mA} / \mathrm{g}$ $\left(\approx 2.0 \mathrm{~mA} / \mathrm{cm}^{2}\right)$ for LFP. After each $25^{\text {th }}$ cycle (up to 100 cycles), the cells were stopped in their discharged state, transferred to a $25^{\circ} \mathrm{C}$ climate chamber, and connected to a Biologic (VMP300) potentiostat for impedance measurements.

For graphite/LFP cells, formation was carried out $25^{\circ} \mathrm{C}$ with $\mathrm{C} / 10$ $\left(0.2 \mathrm{~mA} / \mathrm{cm}^{2}\right)$. Afterwards, 50 cycles were conducted at $40^{\circ} \mathrm{C}$ with a $1 \mathrm{C}$ rate $\left(2 \mathrm{~mA} / \mathrm{cm}^{2}\right)$ between 2.0 and $4.0 \mathrm{~V}$ cell voltage, using a

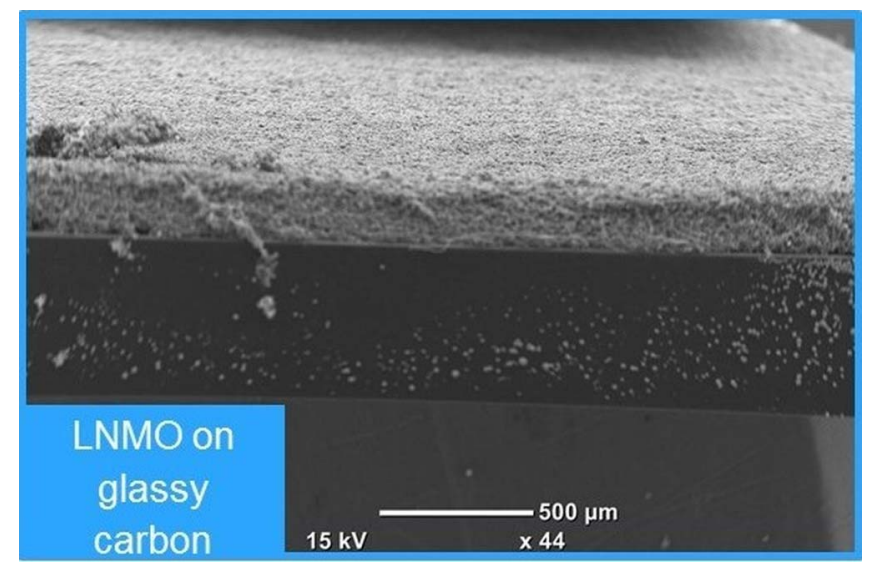

Figure 1. Cross sectional SEM image of an LNMO electrode coating with $\approx 14 \mathrm{mg}_{\mathrm{LNMO}} / \mathrm{cm}^{2}$ (gray top layer) on a glassy carbon disk model current collector (lower black layer), prepared via a slot-coating process. 
$\mathrm{CC}$ discharge and a $\mathrm{CCCV}$ charge protocol with a current limit of $\mathrm{C} / 20$. Impedance was measured at $50 \%$ SOC after formation and after 50 cycles at $25^{\circ} \mathrm{C}$. As electrolyte, a standard LP57 electrolyte (described above) and an LP57 electrolyte containing $\approx 2000 \mathrm{ppm}$ HF were used. The HF-containing LP57 was prepared by adding $1000 \mathrm{ppm}$ (by weight) of deionized water to the electrolyte and stirring for 5 days. As expected based on the literature, ${ }^{21}$ a quantitative conversion of water into HF was confirmed: Karl-Fischer analysis showed that after stirring only $27 \mathrm{ppm}$ of water remained and ${ }^{19}$ F-NMR Spectroscopy showed that $\approx 2000$ ppm of HF were formed.

Electrochemical impedance spectroscopy.-The GWRE was lithiated with a constant current of $150 \mathrm{nA}$ for $1 \mathrm{~h}$ after cell assembly, using the cathode electrode as lithium source (note that the lithiation capacity of $0.15 \mu \mathrm{Ah}$ is negligible compared to the cathode capacity of $\approx 2 \mathrm{mAh}$ ). The detailed procedure for the assembly of T-cells with the GWRE can be found in Reference 19. Potential-controlled impedance spectra were recorded from $100 \mathrm{kHz}$ to $100 \mathrm{mHz}$ with a perturbation of $15 \mathrm{mV}$ at $25^{\circ} \mathrm{C}$ (acquisition time of $10 \mathrm{~min}$./spectrum). Spectra were recorded at two distinct state-of-charge (SOC) values: i) at $4.4 \mathrm{~V}$ cell voltage (corresponding to $\approx 10 \%$ SOC) during discharge at open-circuit (after a prior $1 \mathrm{~h}$ open-circuit hold), and, ii) while holding at $4.9 \mathrm{~V}$ cell voltage ( $\equiv 100 \%$ SOC, i.e., for a fully lithiated cathode), after the voltage had been held at that potential until the current dropped below $\mathrm{C} / 40$. The latter procedure brings the cathode electrode into blocking conditions that are characterized by a very high charge-transfer resistance, so that its impedance response shifts to very low frequencies, enabling a more straightforward impedance analysis in the high- and mid-frequency range. The detailed procedure can be found in Reference 18. In a former study of our group, we showed that the potential stability of the lithiated GWRE is only on the order of several hours in graphite/LNMO cells operating at $40^{\circ} \mathrm{C}$, due to a chemical delithiation of the reference electrode by electrolyte oxidation products. ${ }^{22}$ Therefore, in order to avoid a potential drift of the reference electrode during the impedance measurements, a relithiation of the GWRE with $150 \mathrm{nA}$ for $1 \mathrm{~h}$ was carried out before each electrochemical impedance spectroscopy (EIS) measurement.

\section{Results and Discussion}

Physical origin of the high-frequency semi-circle in LNMO cathodes.-So far, the literature offers two different interpretations about the origin of the high-frequency semi-circle in cathode impedance spectra. On the one hand, this feature has been ascribed to a surface film resistance associated with the formation/growth of a CEI on LNMO cathodes; ${ }^{14,15}$ on the other hand, it has been ascribed to an electronic contact resistance at the cathode electrode/aluminum current collector interface for LFP and LNMO cathodes. ${ }^{18,23}$ Therefore, to clarify this discrepancy in interpretation, we first investigate the effect of the carbon black content of the LNMO cathodes on the high-frequency impedance response, using LNMO cathodes with a carbon black content of either $5 \%$ or $1.5 \%$ at a constant porosity of $\approx 30 \%$ (Type I and Type 2 cathodes, see Table I), which were cycled in a three-electrode cell with graphite as anode and equipped with a gold wire reference electrode (GWRE) to monitor the impedance of the LNMO cathode.

Figure 2a shows the LNMO cathode impedance spectra taken at $4.4 \mathrm{~V}_{\text {Cell }}(\equiv 10 \%$ SOC) for the LNMO cathode with a carbon black content of $5 \%$ after two formation cycles at $25^{\circ} \mathrm{C}$ (in black) and after 50 cycles at $40^{\circ} \mathrm{C}$ (in red). The overall cathode impedance $R_{\text {Cathode }}$ (sum of high and low frequency resistance, highlighted in Figure 2 by blue points) after formation is $\approx 5 \Omega \mathrm{cm}^{2}$ and increases to $\approx 7 \Omega \mathrm{cm}^{2}$ during cycling at $40^{\circ} \mathrm{C}$. The low-frequency semi-circle (apex frequency of $450 \mathrm{~Hz}$ after 50 cycles), which represents a convolution of the charge transfer- and pore resistance, ${ }^{18}$ stays almost constant in size over 50 charge/discharge cycles, but is shifted to higher values on the real axis, owing to the increase of the high-frequency semi-circle (apex frequency $31000 \mathrm{~Hz}$ after 50 cycles). When the carbon black content within the electrode is decreased to $1.5 \%$ (see Figure $2 \mathrm{~b}$ ), $R_{\text {Cathode }}$ af-
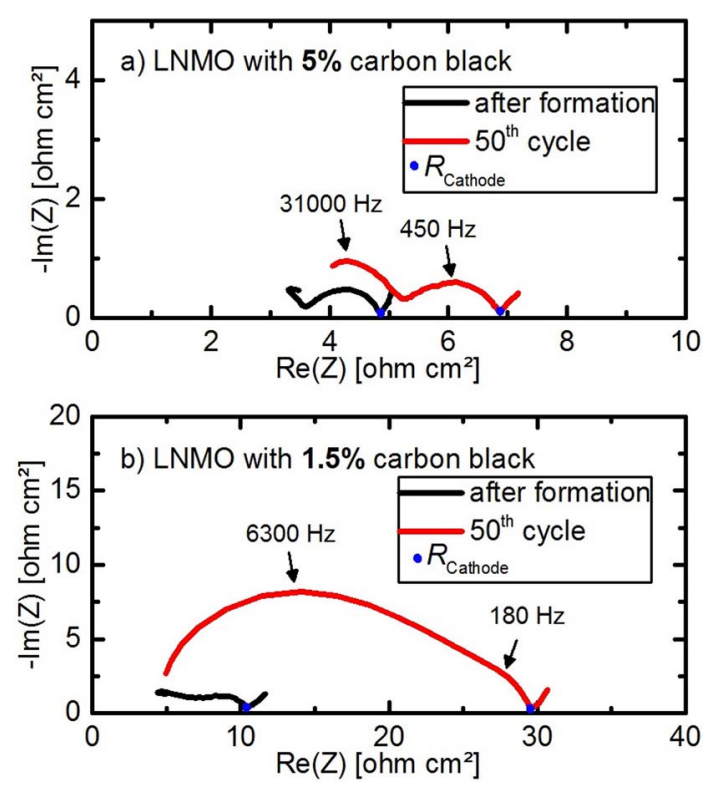

Figure 2. LNMO cathode impedance spectra obtained in graphite/LNMO full-cells after formation at $\mathrm{C} / 10$ and $25^{\circ} \mathrm{C}$ (black line) and after 50 cycles at $\left(2 \times \mathrm{C} / 10+48 \times 1 \mathrm{C}\right.$ cycles) and $40^{\circ} \mathrm{C}$ (red line): a) for an LNMO cathode with 5\% carbon black (Type I, see Table I); b) for an LNMO cathode with $1.5 \%$ carbon black (Type II, see Table I). The impedance was measured from $100 \mathrm{kHz}$ to $100 \mathrm{mHz}$ with a perturbation of $15 \mathrm{mV}$ at $25^{\circ} \mathrm{C}$; it was conducted at $4.4 \mathrm{~V}_{\text {Cell }}$ ( $\equiv 10 \%$ SOC) under open circuit conditions.

ter formation (in black) is higher $\left(\approx 10 \Omega \mathrm{cm}^{2}\right)$, as inidicated by the more pronounced high-frequency semi-circle already after formation. After 50 cycles, $R_{\text {Cathode }}$ increases to $\approx 30 \Omega \mathrm{cm}^{2}$ for the electrodes with $1.5 \%$ carbon black (in contrast to $\approx 7 \Omega \mathrm{cm}^{2}$ for the electrodes with $5 \%$ carbon black), shown by the substantial increase of the highfrequency semi-circle (apex frequency of $6300 \mathrm{~Hz}$ ). Quite clearly, the magnitude of the high-frequency semi-circle increases by $\approx 4$-fold after 50 cycles when the carbon black content is decreased from $5 \%$ to $1.5 \%$. If this impedance feature were related to the CEI resistance of the LNMO, its characteristic capacitance would have to be related to the overall exposed LNMO and carbon black surface area. The latter can be estimated from the BET area $\left(0.9 \mathrm{~m}^{2}{ }_{\mathrm{LNMO}} / \mathrm{g}_{\mathrm{LNMO}}\right)$ and loading $\left(14 \mathrm{mg}_{\mathrm{LNMO}} / \mathrm{cm}^{2}\right.$ electrode $)$ of the active material LNMO, equating to $\approx 126 \mathrm{~cm}^{2}{ }_{\text {LNMO }} / \mathrm{cm}^{2}$ electrode. The surface area of the carbon equates to $447 \mathrm{~cm}^{2}$ for the LNMO cathode with $5 \%$ carbon black (Type I) calculated with a loading of $0.76 \mathrm{mg}_{\text {carbonblack }} / \mathrm{cm}^{2}$ and a BET area of $62 \mathrm{~m}^{2} / \mathrm{g}$. The cathode with $1.5 \%$ carbon black (Type II) has a carbon surface area of $129 \mathrm{~cm}^{2}$ calculated with a loading of $0.22 \mathrm{mg}_{\text {carbonblack }} / \mathrm{cm}^{2}$ and a BET area of $62 \mathrm{~m}^{2} / \mathrm{g}$. By performing an order of magnitude estimate of the characteristic capacitances of the high-frequency semi-circle (fitted with a simple R/Q element, and neglecting the constant phase exponent), the capacitance values after the $50^{\text {th }}$ cycle for the LNMO cathodes with $5 \%$ and $1.5 \%$ carbon black are $\approx 2.5 \mu \mathrm{F} / \mathrm{cm}^{2}$ electrode and $\approx 1.3 \mu \mathrm{F} / \mathrm{cm}^{2}$ electrode. If this were due to the LNMO surface, i.e., due to a CEI resistance, the surface area normalized capacitances

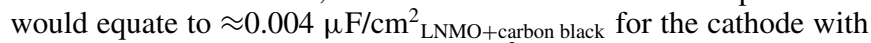
$5 \%$ carbon black and to $\approx 0.005 \mu \mathrm{F} / \mathrm{cm}^{2}{ }_{\text {LNMO+carbon black for the cath- }}$ ode with $1.5 \%$ carbon black, which unquestionably is far too low for a typical electrochemical double-layer capacitance that, if referenced to the actual surface area, should be on the order of $\approx 10^{1}$ $\mu \mathrm{F} / \mathrm{cm}^{2} .{ }^{17}$ On the other hand, if normalized to the aluminum current collector surface $\left(\approx 1 \mathrm{~cm}^{2}\right)$, a reasonable double-layer capacitance of $\approx 1.3-2.5 \mu \mathrm{F} / \mathrm{cm}^{2}{ }_{\mathrm{Al}}$ is obtained, which strongly suggests that the electrochemically active surface which is represented by the highfrequency semi-circle is the interface between the cathode electrode and the aluminum current collector.

In order to confirm that the high-frequency semicircle indeed is due to an electronic resistance at the LNMO cathode/aluminum current 

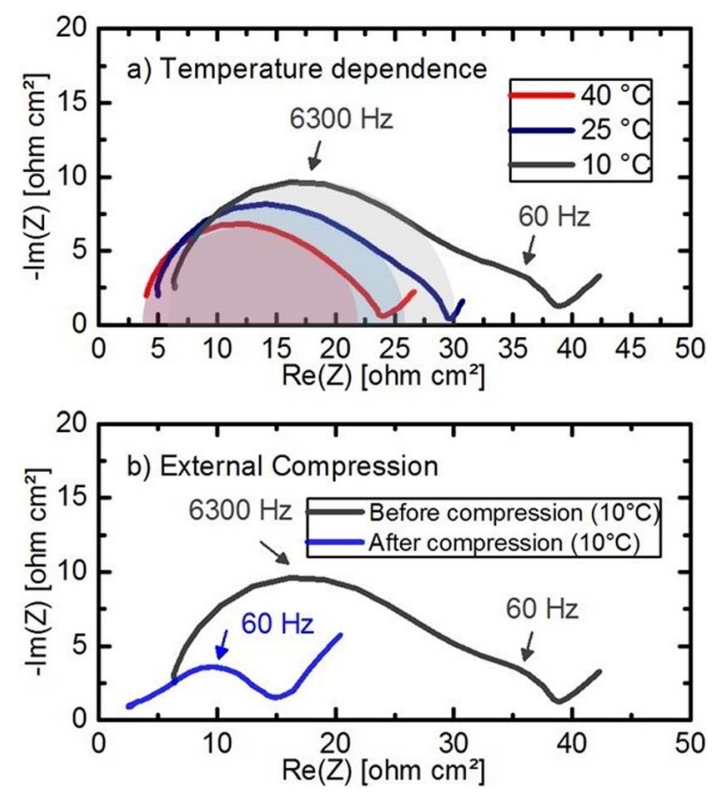

Figure 3. LNMO cathode impedance spectra obtained after 50 cycles at $1 \mathrm{C}$ and $40^{\circ} \mathrm{C}$ in graphite/LNMO cells based on LNMO cathodes with $1.5 \%$ carbon black (Type II cathode, see Table I). a) Cathode impedance measured at $10^{\circ} \mathrm{C}, 25^{\circ} \mathrm{C}$, and $40^{\circ} \mathrm{C}$; before recording the impedance, two hours of an $\mathrm{OCV}$ period was carried out to assure thermal equilibration. b) Impedance spectrum (recorded at $10^{\circ} \mathrm{C}$ ) of a cycled LNMO cathode before and after external compression of the T-cell. The impedance was measured from $100 \mathrm{kHz}$ to $100 \mathrm{mHz}$ with a perturbation of $15 \mathrm{mV}$ at $25^{\circ} \mathrm{C}$; it was conducted at $4.4 \mathrm{~V}_{\text {Cell }}(\equiv 10 \%$ SOC) under open circuit conditions.

collector interface, the impedance of an LNMO cathode with $1.5 \%$ carbon black after 50 cycles is measured at different temperatures. Temperature-dependent impedance measurements give information about the activation energy of processes happening at interfaces in porous electrodes. ${ }^{24}$ Figure 3 a shows the cathode impedance spectra measured at three different temperatures, namely $40^{\circ} \mathrm{C}$ (red), $25^{\circ} \mathrm{C}$ (blue), and $10^{\circ} \mathrm{C}$ (gray). As expected, the cathode impedance over the whole frequency range increases when reducing the temperature; however, the extent of the change differs considerably for the different impedance features. The high-frequency semi-circle (simply fitted with an R/Q element, shown by the shaded areas in Figure 3a) increases from $\approx 17 \Omega \mathrm{cm}^{2}$ (at $40^{\circ} \mathrm{C}$ ) to $\approx 19 \Omega \mathrm{cm}^{2}$ (at $25^{\circ} \mathrm{C}$ ) to $\approx 23 \Omega \mathrm{cm}^{2}$ (at $10^{\circ} \mathrm{C}$ ). The associated activation energy, determined by fitting a linear regression line to a plot of the logarithm of $1 / R_{\text {high-frequency }}$ versus $1 / T$ (in Kelvin) and by multiplying the slope by the universal gas constant $R(8.314 \mathrm{~J} / \mathrm{molK})$, results in an apparent activation energy of $\approx 3 \mathrm{~kJ} / \mathrm{mol}$. This is in reasonably good agreement with the activation energy of an electronic resistance of $\approx 1 \mathrm{~kJ} / \mathrm{mol}$ as reported by Ogihara et al., ${ }^{24}$ and is much lower than what one would expect for the CEI resistance and what was reported for the charge-transfer resistance $\left(\approx 60 \mathrm{~kJ} / \mathrm{mol}^{24}\right)$. This, however, leaves the question as to where the LNMO charge-transfer resistance would appear in the impedance spectra of Figure 3a. For LNMO cathodes with $5 \%$ carbon black (identical to Type I), we determined its value at $40^{\circ} \mathrm{C}$ to be $\approx 0.5$ $\Omega \mathrm{cm}^{2}$, which explains why it can only be discerned vaguely in the impedance spectrum at $40^{\circ} \mathrm{C}$ in Figure $3 \mathrm{a} .{ }^{18}$ However, as the temperature is being decreased, a well pronounced low-frequency semicircle appears, which we associate with the LNMO charge-transfer and pore resistance. At $10^{\circ} \mathrm{C}$, the resistance of this low-frequency semi-circle is $\approx 10 \Omega \mathrm{cm}^{2}$ (this will be seen more clearly in Figure $3 \mathrm{~b}$ ) and it has an apex frequency of $60 \mathrm{~Hz}$, which corresponds to a capacitance of $\approx 265 \mu \mathrm{F} / \mathrm{cm}^{2}$ electrode. By including the pore resistance in the calculation of the double layer capacitance, an error is introduced. However, in order to get information about the order of magnitude we think that taking both charge transfer and pore resistance is sufficient. If normalized to the LNMO and carbon black surface area $\left(\approx 126 \mathrm{~cm}^{2}{ }_{\text {LNMO }} / \mathrm{cm}^{2}\right.$ electrode and $\approx 129 \mathrm{~cm}^{2}$ carbon black $/ \mathrm{cm}^{2}$ electrode), a very reasonable interfacial capacity of $\approx 0.1 \cdot 10^{1} \mu \mathrm{F} / \mathrm{cm}^{2}$ LNMO is again obtained, clearly indicating that the low-frequency feature is related to the LNMO charge-transfer resistance. This is further supported by the strong temperature dependence of the low-frequency semi-circle resistance, increasing by approximately one order of magnitude when lowering the temperature from $40^{\circ} \mathrm{C}$ to $10^{\circ} \mathrm{C}$ (unfortunately, the error in determining the low-frequency semi-circle resistance at $40^{\circ} \mathrm{C}$ from Figure $3 \mathrm{a}$ is too large for a precise quantification, which would require an experimental methodology as described in Reference 18).

After performing temperature-dependent impedance measurements, the T-cell was compressed by applying an external force. It is expected, that a compression of the cathode will improve the quality of the contact between the current collector and the LNMO coating, while the charge transfer resistance across a possible surface film (CEI) should stay relatively constant. Figure $3 \mathrm{~b}$ shows the impedance spectrum of the LNMO cathode measured at $10^{\circ} \mathrm{C}$ before compression (gray line, already shown in Figure $3 \mathrm{a}$ and discussed above). After external compression of the T-cell, several changes can be observed in the impedance spectrum (Figure 3b, in blue): (i) the high-frequency semi-circle with an apex frequency of $6300 \mathrm{~Hz}$ is no longer present, (ii) the low-frequency semi-circle retains the same apex frequency of $60 \mathrm{~Hz}$ but shifts to lower values along the $\mathrm{x}$-axis, and, (iii) the highfrequency resistance intercept also shifts toward lower values, as the thickness of the glass fiber separators decreases substantially upon compression. The external compression clearly leads to an improved electrical contact at the interface between the cathode electrode and the aluminum current collector, analogous to what has been observed before with LFP electrodes. ${ }^{23,25}$ Thus, the analysis of its characteristic capacitance, of its temperature-dependence, and of its dependence upon cell compression clearly demonstrates that the semi-circle at high-frequencies is due to an electronic contact resistance at the interface between the cathode electrode and the aluminum current collector. It therefore rules out definitively the interpretation in the literature that it be due to a surface-film (CEI) resistance.

Aluminum vs. glassy carbon current collector.-In order to find out if the increase in the contact resistance $\left(R_{\text {Contact }}\right)$ is due to the corrosion of the conductive carbon at the interface or from the formation of a resistive surface film on the aluminum current collector, the aluminum cathode current collector is replaced by a glassy carbon disk. The rationale of this approach is that the glassy carbon surface cannot form a resistive passivation layer at high voltages, contrary to the possible formation of, for example, a resistive $\mathrm{AlF}_{3}$ layer on the aluminum current collector. As the glassy carbon disks break upon compression, the following cathodes - LNMO on aluminum and LNMO on glassy carbon - are both tested without compression (see Type 3 and Type 4 in Table I), even though LNMO electrodes usually are compressed or calendered. As before, formation of these cells is done at $\mathrm{C} / 10$ at $25^{\circ} \mathrm{C}$ for two cycles, followed by 98 cycles at $1 \mathrm{C}$ and $40^{\circ} \mathrm{C}$. After each $25^{\text {th }}$ cycle, the cells are transferred to a $25^{\circ} \mathrm{C}$ chamber, where the EIS experiments are performed. Figure $4 \mathrm{a}$ shows the specific discharge capacity for graphite/LNMO cells with the cathode coated either on glassy carbon (red dots) or on aluminum foil (green dots), and Figure $4 \mathrm{~b}$ shows the voltage profiles of the graphite/LNMO cells after the $2^{\text {nd }}$ and the $25^{\text {th }}$ cycle at $1 \mathrm{C}$.

For both cathode types, the first discharge capacity at $0.1 \mathrm{C}$ is $\approx 121 \pm 1 \mathrm{mAh} / \mathrm{g}_{\text {LNMO }}$, which is in good agreement with previous measurements with LNMO cathodes (compressed, with 5\% carbon black) tested under identical conditions. ${ }^{20}$ After formation, the fullcell voltage profiles of the $2^{\text {nd }}$ cycle at $1 \mathrm{C}$ are essentially identical for the cell with an LNMO cathode coated on an aluminum current collector (Figure 4b, dashed green line) and for that with an LNMO cathode coated on a glassy carbon disk (Figure $4 \mathrm{~b}$, dashed red line), indicating a similar impedance after formation. After 98 cycles at $1 \mathrm{C}$ (i.e., the $100^{\text {th }}$ cycle in Figure $4 \mathrm{a}$ ), the remaining discharge capacity is $\approx 91 \pm 1 \mathrm{mAh} / \mathrm{g}_{\text {LNMO }}$ for cells with LNMO coated on glassy carbon and $\approx 86 \pm 7 \mathrm{mAh} / \mathrm{g}_{\mathrm{LNMO}}$ for cells with an aluminum current collector. 

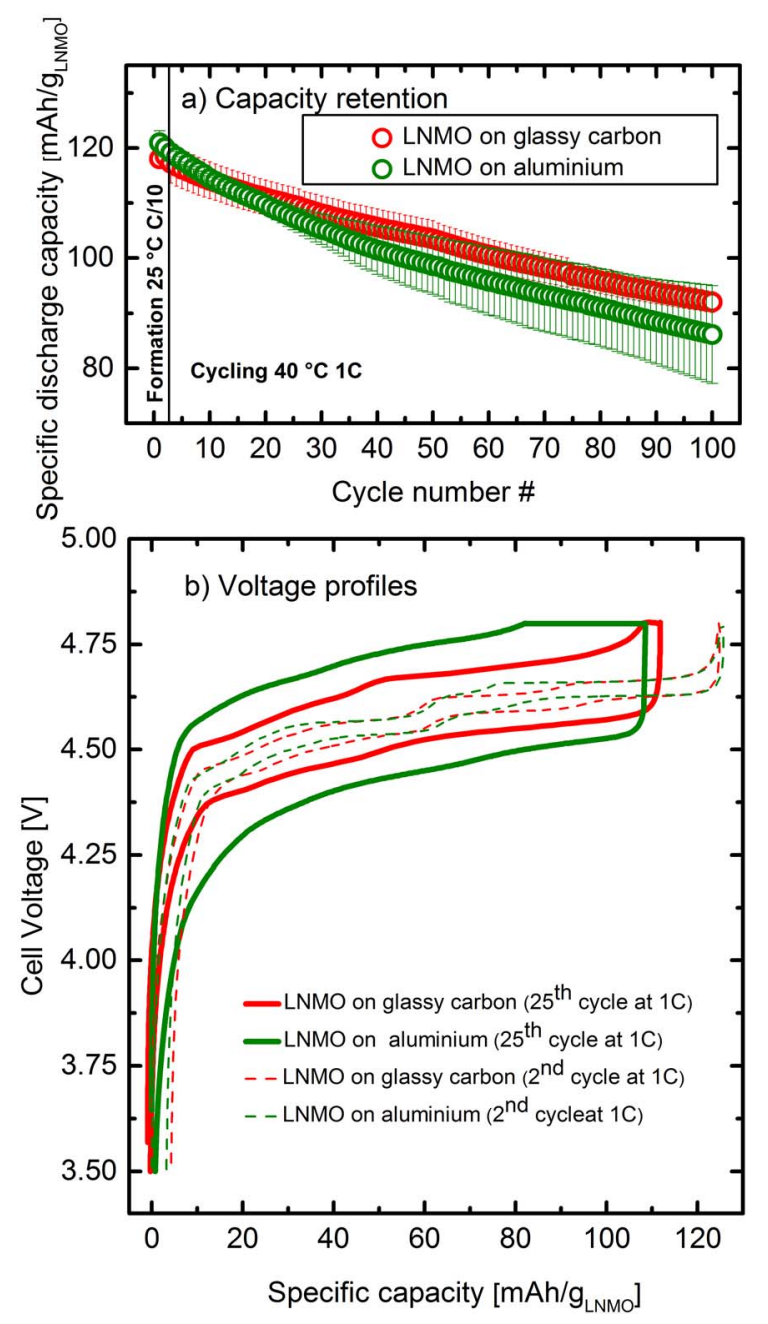

Figure 4. a) Specific discharge capacity (in $\mathrm{mAh} / \mathrm{g}_{\mathrm{LNMO}}$ ) versus cycle number of graphite/LNMO cells with uncompressed LNMO cathodes either coated on aluminum (green circles; Type III electrodes, see Table I) or on glassy carbon (red circles; Type IV electrodes, see Table I) over extended charge/discharge cycling at $1 \mathrm{C}$ (CCCV charge, CC discharge) between 3.5-4.8 V cell voltage at $40^{\circ} \mathrm{C}$ with an LP57 electrolyte. Formation ( 2 cycles) was carried out at $\mathrm{C} / 10$ and $25^{\circ} \mathrm{C}$. The error bars represent the standard deviation of two cells. b) Corresponding cell voltage profiles of the $2^{\text {nd }}$ cycle at $1 \mathrm{C}$ (dotted lines) and for the $25^{\text {th }}$ cycle at $1 \mathrm{C}$ (solid lines).

The cycling performance of these full-cells lies well within the capacity retention obtained in our previous study $\left(\approx 90 \pm 1 \mathrm{mAh} / \mathrm{g}_{\mathrm{LNMO}}\right.$ after the $98^{\text {th }}$ cycle at $1 \mathrm{C}$ and $40^{\circ} \mathrm{C}$ )..$^{22}$ Here it may be noted that while the capacity fading of both cells is initially very similar, it starts to differ after $\approx 25$ cycles, where the capacity of the LNMO cathodes coated on aluminum fade slightly faster and where a significant capacity variation between the two nominally identical cells starts to develop (green symbols in Figure 4a). This is accompanied by the development of a substantial cell impedance, particularly in the case of the LNMO cathodes coated on aluminum, as can be seen from the voltage profiles after the $25^{\text {th }}$ cycle at $1 \mathrm{C}$ (solid lines in Figure $4 \mathrm{~b}$ ). The much more increased polarization of the cells with the LNMO coated on aluminum compared to the LNMO coated on glassy carbon results in a rapid increase of the capacity contribution from the $\mathrm{CV}$ step for the former. The nevertheless similar capacity retention of both cathode types can thus only be reached because the CV step with a current limit of $\mathrm{C} / 20$ compensates for the much higher overpotential apparent in the cell using the LNMO cathode coated on aluminum (note that its energy retention would be inferior due its much lower average discharge voltage).
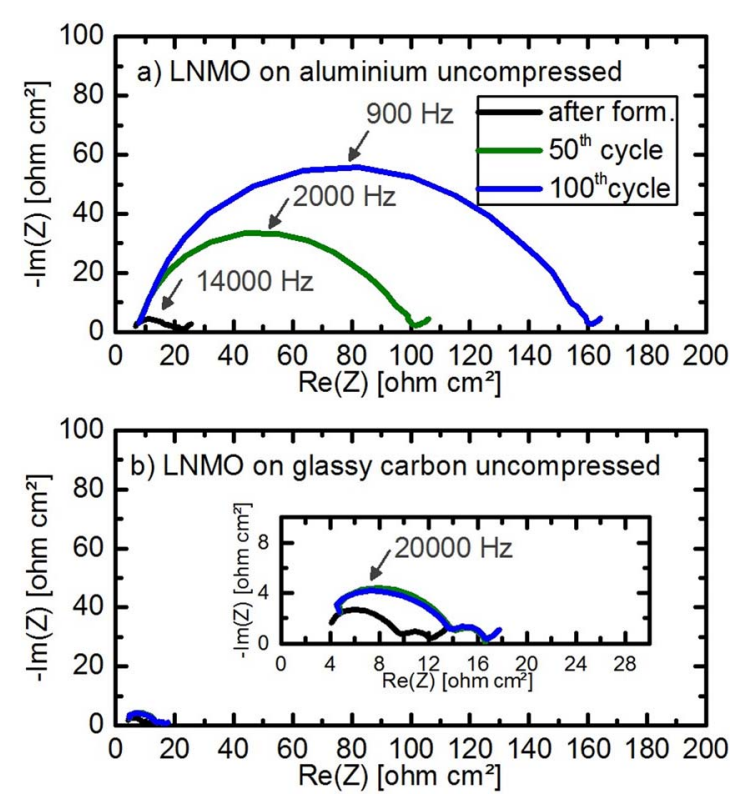

Figure 5. Impedance spectra of uncompressed LNMO cathodes with $1.5 \%$ carbon black after two formation cycles at $0.1 \mathrm{C}$ at $25^{\circ} \mathrm{C}$, and after the $50^{\text {th }}$ and $100^{\text {th }}$ cycle (i.e, after 48 and 98 cycles at $1 \mathrm{C}$ and $40^{\circ} \mathrm{C}$ ) in a graphite/LNMO cell. a) Impedance response of an uncompressed LNMO cathode coated on an aluminum current collector (Type III electrodes, see Table I); b) Impedance response of an LNMO cathode coated on a glassy carbon disk; the inset is a magnified view. The impedance was measured from $100 \mathrm{kHz}$ to $100 \mathrm{mHz}$ with a perturbation of $15 \mathrm{mV}$ at $25^{\circ} \mathrm{C}$; it was conducted at $4.4 \mathrm{~V}_{\text {Cell }}$ ( $\equiv 10 \% \mathrm{SOC}$ ) under open circuit conditions.

In order to investigate the origin of the increased overpotential of graphite/LNMO cells with an aluminum current collector, the cathode impedance responses at $4.4 \mathrm{~V}$ cell voltage (i.e., at $\approx 10 \%$ SOC) are shown for graphite/LNMO cells with an aluminum current collector (Figure 5a) and graphite/LNMO cells with a glassy carbon current collector (Figure 5b). Figure 5a shows the large increase of the overall impedance over cycling, which is consistent with the above observed increased cell polarization (Figure $4 \mathrm{~b}$ ). The observed impedance response in each case is dominated by a high-frequency semi-circle, whereby the approximate capacitances derived from a simple R/Q fit are $\approx 0.8 \mu \mathrm{F} / \mathrm{cm}^{2}$ for the $50^{\text {th }}$ cycle (in green) and $\approx 1.1 \mu \mathrm{F} / \mathrm{cm}^{2}$ after the $100^{\text {th }}$ cycle (in blue), consistent with an electronic contact resistance. The overall cathode resistance $R_{\text {Cathode }}$ increases from $\approx 22 \Omega \mathrm{cm}^{2}$ after formation to $\approx 100 \Omega \mathrm{cm}^{2}$ after 50 cycles and to $\approx 160 \Omega \mathrm{cm}^{2}$ after 100 cycles, an increase which is clearly governed by the large increase of the high-frequency semi-circle. Compared to compressed cathodes from the experiments before (see Figure 2 and Figure 3), the high-frequency semi-circle impedance is substantially larger, thus indicating that uncompressed electrodes have an inferior electrical contact at the interface of the cathode electrode and the current collector. A more rigorous deconvolution of the high-frequency semi-circle from the low-frequency semi-circle will be shown in the next section.

Interestingly, the cathode impedance of graphite/LNMO cells with a glassy carbon current collector (see Figure 5b) is much lower compared to cells with an aluminum current collector (compare 5a). The cathode resistance $R_{\text {Cathode }}$ after formation is $\approx 12 \Omega \mathrm{cm}^{2}$ and increases only slightly to $\approx 16 \Omega \mathrm{cm}^{2}$ after 50 cycles due to an increase in the high-frequency semi-circle and then stays constant up to 100 cycles. The slight increase of the high-frequency semi-circle might arise from the corrosion of the glassy carbon substrate or the carbon black in the coating when the temperature is increased from $25^{\circ} \mathrm{C}$ (during formation) to $40^{\circ} \mathrm{C}$ (during cycling). Quite clearly, after 100 cycles, the overall cathode resistance $R_{\text {Cathode }}$ of cells with an aluminum current collector is an order of magnitude higher $\left(\approx 160 \Omega \mathrm{cm}^{2}\right)$ compared to 
the cells with LNMO coated on glassy carbon $\left(\approx 16 \Omega \mathrm{cm}^{2}\right)$. In summary, we can now clearly attribute the high-frequency semi-circle to a contact resistance $\left(R_{\text {Cont. }}\right)$ between the aluminum current collector and the LNMO coating, whereby the major increase of $R_{\text {Cont. }}$ over extended cycling seems to be caused by the formation of a resistive surface film on the aluminum current collector. In addition, the strong dependence of the evolution of $R_{\text {Cont. }}$ on the type of current collector also rules out an inter-particle contact resistance within the LNMO electrode, as this effect would be independent of the current collector material.

Quantification of $\boldsymbol{R}_{\text {Cont. }}$ by the blocking condition methodology.-In a recent study ${ }^{18}$ of our group, we introduced a novel impedance procedure which enabled a quantitative deconvolution of the LNMO cathode impedance $\left(R_{\text {Cathode }}\right)$ into contributions from the charge transfer resistance $\left(R_{\mathrm{CT}}\right)$, the pore resistance $\left(R_{\text {Pore }}\right)$, and the contact resistance between current collector and cathode electrode $\left(R_{\text {Cont. }}\right)$. At that time, we quantified the various resistances by recording impedance spectra at two distinct state-of-charge (SOC) values of an LNMO cathode in a graphite/LNMO cell: (i) at $4.4 \mathrm{~V}$ cell voltage (corresponding to $\approx 10 \%$ SOC) during discharge, acquired at open-circuit voltage (after a $1 \mathrm{~h}$ open-circuit hold), and, (ii) while holding at $4.9 \mathrm{~V}$ cell voltage, after the potential had been held at this voltage until the current had dropped to $\mathrm{C} / 40$, so that the LNMO is completely delithated, corresponding to a full-cell SOC of $100 \%$. At the latter condition, the LNMO charge-transfer resistance becomes very large due to the suppression of lithium intercalation (representing blocking conditions), so that its impedance response shifts to very low frequencies. Therefore, by recording the impedance at $4.9 \mathrm{~V}$ cell voltage, the impedance spectrum shows features distinctly separated in frequency space: a high-frequency semi-circle for the contact resistance $\left(R_{\text {Contact }}\right)$, a mid-frequency $45^{\circ}$ transmission-line feature representing $1 / 3$ of the pore resistance $\left(R_{\text {Pore }}\right)$, and at very low frequencies a very large charge transfer resistance $\left(R_{\mathrm{CT}}\right)$. Meaningful quantitative values for these resistances can be obtained by simultaneously fitting the spectra at $4.4 \mathrm{~V}$ cell voltage (non-blocking conditions) and at $4.9 \mathrm{~V}$ cell voltage (blocking conditions) to a transmission-line model equivalent circuit that is connected in series with an R/Q element for the contact resistance $\left(R_{\text {Cont. }}\right)$, and with a Warburg element accounting for concentration gradients within the separator (for further details, see Reference 18). The same principle is applied in this study, and an exemplary impedance spectrum in blocking- and non-blocking conditions for an LNMO cathode ( $1.5 \%$ carbon black, compressed) after the $48^{\text {th }}$ cycle at $1 \mathrm{C}$ and $40^{\circ} \mathrm{C}$ is shown in Figure 6.

Figure 6 shows the non-blocking impedance spectrum (blue symbols) and the blocking impedance spectrum (red circles) after 48 cycles at $1 \mathrm{C}$ and $40^{\circ} \mathrm{C}$. The high-frequency semi-circle is present in both spectra, which supports its assignment to a contact resistance $\left(R_{\text {Cont. }}\right)$, as this resistance should not change with SOC. At lower frequencies, a Warburg $45^{\circ}$-line is observed for the spectrum in non-blocking conditions, whereas in the blocking spectrum a large impedance feature is observed for the large charge transfer resistance $\left(R_{\mathrm{CT}}\right)$. In our previous study, ${ }^{18}$ using an LNMO cathode with a carbon black content of $5 \%$, a pronounced $45^{\circ}$ transmission-line feature at mid-frequencies was observed in the blocking spectrum. However, for the low carbon black content $(1.5 \%)$ in the LNMO cathodes used in this study, the larger values for the contact resistance $\left(R_{\text {Cont. }}\right)$ result in a larger highfrequency semi-circle that masks the $45^{\circ}$ transmission-line feature in the mid-frequency range. As shown in our previous study, the value for the pore resistance after formation is $R_{\text {Pore }} \approx 3.2 \Omega \mathrm{cm}^{2}$, which only increases slightly upon cycling at $40^{\circ} \mathrm{C}(\approx 1.5$-fold over 85 cycles $) .{ }^{18}$ Hence, we here use this $R_{\text {Pore }}$ value for fitting the spectra in nonblocking and blocking condition with a transmission-line equivalent circuit, neglecting the slight increase of $R_{\text {Pore }}$ over extended cycling. While it is clear that this simplification will not allow a deconvolution of all resistances with a high accuracy, the error for quantifying $R_{\text {Cont. }}$ is rather small, as it represent the by far largest contribution to the overall cathode impedance.

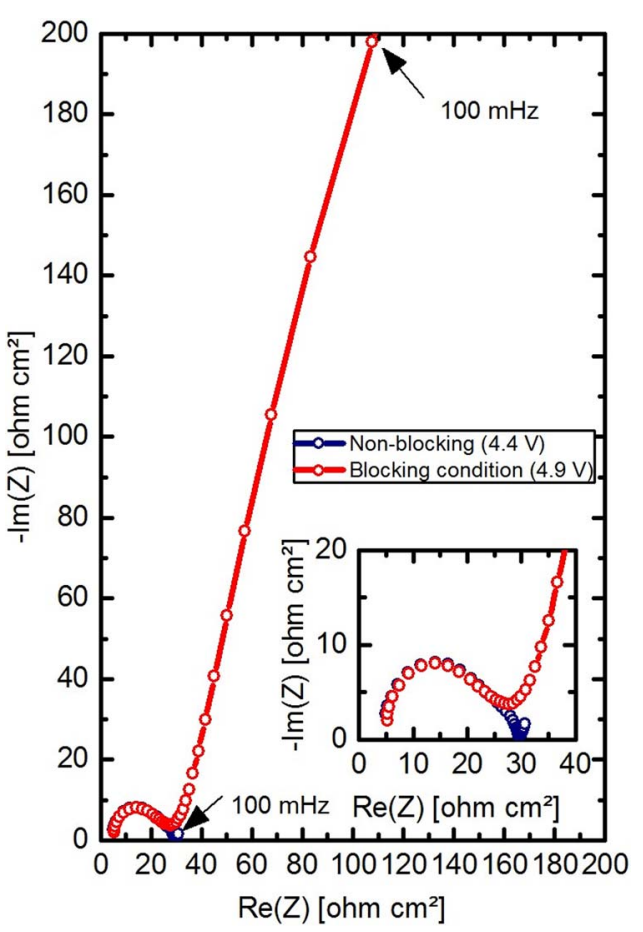

Figure 6. Impedance spectra of a compressed LNMO cathode with $1.5 \%$ carbon black (Type II in Table I) after the $48^{\text {th }}$ cycle in a graphite/LNMO cell at $1 \mathrm{C}$ and $40^{\circ} \mathrm{C}$ measured in non-blocking conditions (at $4.4 \mathrm{~V}$ cell voltage or $\approx 10 \%$ SOC, in blue) or in blocking conditions (at $4.9 \mathrm{~V}$ cell voltage or $100 \%$ $\mathrm{SOC}$, in red). The impedance was recorded from $100 \mathrm{kHz}$ to $100 \mathrm{mHz}$ with a perturbation of $15 \mathrm{mV}$ at $25^{\circ} \mathrm{C}$. For blocking conditions, the cell voltage was held at $4.9 \mathrm{~V}$ until the current decreased to $\mathrm{C} / 40$ and the impedance was recorded while holding at $4.9 \mathrm{~V}$; for non-blocking conditions, the impedance was recorded at open-circuit. The inset is a magnified view of the high- to mid-frequency region.

Figure 7 shows the thus fitted $R_{\text {Cont. }}$ values for three different LNMO cathodes with $1.5 \%$ carbon black, cycled in graphite/LNMO cells at $1 \mathrm{C}$ and $40^{\circ} \mathrm{C}$ (including two formation cycles at $0.1 \mathrm{C}$ and $25^{\circ} \mathrm{C}$ ), namely for: (i) LNMO coated on glassy carbon (Type IV in Table I; red circles), (ii) LNMO coated on aluminum and uncompressed (Type III in Table I green circles), and, (iii) LNMO coated on aluminum which is compressed at $200 \mathrm{MPa}$ to $30 \%$ porosity (Type II in Table I; black circles). Cells with an uncompressed cathode on aluminum (green circles in Figure 7) show a large linear increase of $R_{\text {Cont. }}$ over 100 cycles to $\approx 160 \pm 12 \Omega \mathrm{cm}^{2}$. When the same electrodes were compressed to a porosity of $30 \%$ prior to cycling, $R_{\text {Cont. }}$ increases less dramatically to $\approx 38 \pm 8 \Omega \mathrm{cm}^{2}$ after 100 cycles. In contrast, LNMO electrodes coated on a glassy carbon disk show essentially no increase in contact resistance over cycling, exhibiting a contact resistance of $\approx 14 \pm 6 \Omega \mathrm{cm}^{2}$ after 100 cycles.

It is well known that the aluminum current collector in lithium-ion batteries is covered by a thin layer of native oxide $\mathrm{Al}_{2} \mathrm{O}_{3}$ which protects the otherwise reactive metal from corrosion up to potentials of about $4 \mathrm{~V} \mathrm{vs.} \mathrm{Li}^{+} / \mathrm{Li}^{26-28}$ It has also been shown that the aluminum surface is further passivated by a layer of $\mathrm{AlF}_{3}$ when fluorinated species such as $\mathrm{LiPF}_{6}$ or $\mathrm{LiBF}_{4}$ are used as conductive salt in non-aqueous electrolytes, ${ }^{28-31}$ or when $\mathrm{HF}$ is added to electrolytes containing more stable salts like $\mathrm{LiCF}_{3} \mathrm{SO}_{2}$ or $\mathrm{Li}\left(\mathrm{CF}_{3} \mathrm{SO}_{2}\right)_{2} \mathrm{~N}$. ${ }^{27}$ Since graphite/LNMO full cells are typically cycled up to a cathode potential of $4.9 \mathrm{~V}$ vs. $\mathrm{Li}^{+} / \mathrm{Li}$, it is reasonable to assume that the (electro)chemical oxidation of the electrolyte might result in reaction products which can either oxidize or other passivate the aluminum surface, thereby increasing the contact resistance at the Al/LNMO interface. We recently provided evidence that the (electro)chemical oxidation of alkyl carbonates in commonly used electrolytes leads to the formation of protic species, ${ }^{12}$ later on, Ma et al. ${ }^{30}$ argued that these protic species would react with 


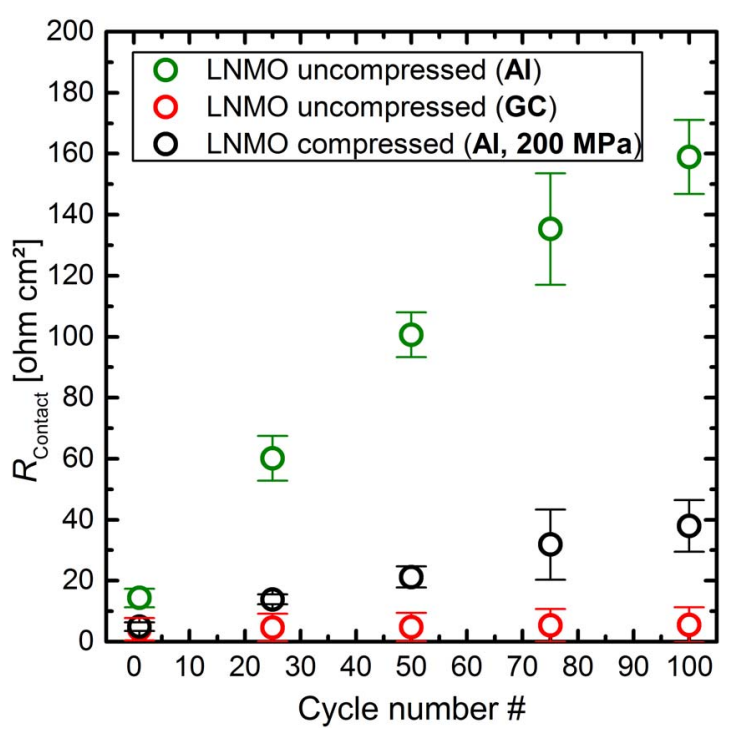

Figure 7. Contact resistances for LNMO cathodes (with $1.5 \%$ carbon black) cycled in graphite/LNMO cells (at $1 \mathrm{C}$ and $40^{\circ} \mathrm{C}$, after 2 formation cycles at $0.1 \mathrm{C}$ and $25^{\circ} \mathrm{C}$ ), as determined from a simultaneous fit of impedance spectra measured in blocking- and non-blocking conditions (see Figure 6) with a transmission-line equivalent circuit as described in Reference 18. Green circles: uncompressed LNMO cathodes on aluminum (Type III, see Table I); black circles: compressed LNMO cathodes on aluminum (Type II, see Table I); red circles: LNMO cathodes on glassy carbon (Type IV, see Table I). The error bar represents the standard deviation of two cells and the first data points represent $R_{\text {Cont }}$. after two formation cycles at C/10.

$\mathrm{LiPF}_{6}$ to $\mathrm{HF}$, which in turn would convert the (oxidized) aluminum surface to the $\mathrm{AlF}_{3}$ surface layer they had observed by XPS. This is consistent with the facts that (i) protic species rapidly react with $\mathrm{LiPF}_{6}$ to $\mathrm{HF}^{32}$ and that (ii) the addition of $\mathrm{HF}$ into electrolytes with more stable salts also leads to $\mathrm{AlF}_{3}$ formation, as determined by XPS. ${ }^{27}$ We therefore believe that the protic species produced by the electrochemical electrolyte oxidation reaction at the LNMO cathode in graphite/LNMO full cells gradually converts the native aluminum oxide surface film into a growing layer of $\mathrm{AlF}_{3}$, thereby degrading the quality of the electronic contact at the Al/LNMO interface. Furthermore, the reported pitting corrosion on aluminum current collectors cycled in an $\mathrm{LiPF}_{6}$ containing electrolyte could also contribute to the observed increasing contact resistance over cycling. ${ }^{28}$ In either case, this explains why a growing contact resistance is only observed for LNMO cathode coated on aluminum and not on glassy carbon, which would not form an insulating layer with HF (see Figure 7). Comparing compressed and uncompressed LNMO electrodes coated on aluminum (green and black symbols in Figure 7), the linear increase of $R_{\text {Cont. }}$ over cycling is lower for compressed electrodes, underlining that the Al/LNMO interface conductivity upon compression is improved, even though an insulating surface layer continues to grow over cycling. This result also demonstrates that compression of high-voltage cathodes is very important, as the increasing resistance lowers the energy density of the cells. In the following section, we investigate the evolution of $R_{\text {Cont }}$. in the absence of electrolyte oxidation, which can be done by examining $R_{\text {Cont }}$. vs. cycle number in graphite/LFP cells.

Investigation of the cathode/aluminum contact resistance in graphite/LFP cells.-In order to prove that the presence/formation of HF really causes the growth of the above discussed interfacial contact resistance, we introduced a controlled amount of HF into the electrolyte of a graphite/LFP cell. Since these cells are typically cycled to an upper cutoff cell voltage of $4.0 \mathrm{~V}$, corresponding to a maximum cathode potential of only $\approx 4.1 \mathrm{~V}$ vs. $\mathrm{Li}^{+} / \mathrm{Li}$, the electrolyte should be stable against oxidation, so that the impact of $\mathrm{HF}$ on the cathode impedance response can be observed independent of
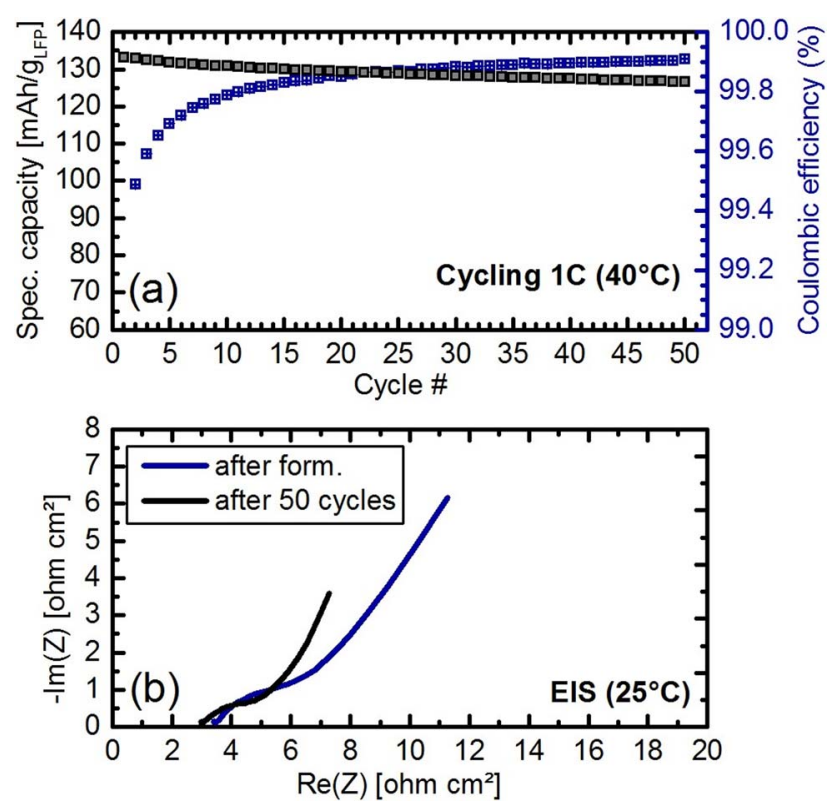

Figure 8. a) Specific discharge capacity (black symbols) and coulombic efficiency (blue symbols) of graphite/LFP cells cycled with pristine LP57 electrolyte between $2.0-4.0 \mathrm{~V}$ at $1 \mathrm{C}$ and $40^{\circ} \mathrm{C}$ (CCCV charge until $\mathrm{C} / 20$, and $\mathrm{CC}$ discharge). Two Formation was done at $\mathrm{C} / 10$ and $25^{\circ} \mathrm{C}$ ( 2 cycles, not shown). b) Impedance spectra of an LFP cathode measured at $50 \%$ SOC after formation (blue line) and after 50 cycles (black line). The impedance is recorded from $100 \mathrm{kHz}$ to $100 \mathrm{mHz}$ with a perturbation of $15 \mathrm{mV}$ at $25^{\circ} \mathrm{C}$ under open circuit conditions.

other effects which might be caused by electrolyte oxidation. For this purpose, a sample of the standard LP57 electrolyte was mixed with $1000 \mathrm{ppm}$ of deionized water and stirred for 5 days. As previously reported in the literature, water reacts with $\mathrm{LiPF}_{6}$ according to the following mechanism: ${ }^{33,34}$

$$
\begin{gathered}
\mathrm{LiPF}_{6} \rightleftharpoons \mathrm{LiF} \downarrow+\mathrm{PF}_{5} \\
\mathrm{PF}_{5}+\mathrm{H}_{2} \mathrm{O} \rightarrow \mathrm{POF}_{3}+2 \mathrm{HF}
\end{gathered}
$$

Consistent with the literature, ${ }^{21}$ the completion of these reactions after 5 days was confirmed by Karl-Fischer-Titration and by ${ }^{19} \mathrm{~F}$ NMR (experimental section), yielding $\approx 2000 \mathrm{ppm}$ HF. To investigate the effect of HF on the cathode impedance, T-cells with the LP57 electrolyte without and with $\approx 2000 \mathrm{ppm}$ HF were assembled as described in the experimental section. For each cell, impedance spectra of the cathode were acquired at open circuit-conditions at $50 \%$ SOC and $25^{\circ} \mathrm{C}$ (non-blocking conditions), both after two formation cycles $(\mathrm{C} / 10$ at $\left.25^{\circ} \mathrm{C}\right)$ and after 50 charge/discharge cycles $\left(1 \mathrm{C}\right.$ at $\left.40^{\circ} \mathrm{C}\right)$. The cycling data and the cathode impedance spectra of the cell containing the pure LP57 electrolyte (without added HF) are shown in Figure 8. The specific discharge capacity at $1 \mathrm{C}$ decreases from $\approx 133 \mathrm{mAh} / \mathrm{g}_{\mathrm{LFP}}$ to $\approx 127 \mathrm{mAh} / \mathrm{g}_{\text {LFP }}$ over the course of 50 cycles (capacity retention of $\approx 95 \%$ ), with coulombic efficiencies increasing from $99.4 \%$ to $99.9 \%$. The impedance spectra at $50 \%$ SOC both before and after cycling do not show a visible high frequency semi-circle, which indicates that the contact resistance is negligible. We believe that the minor but noticeable onset for a contact resistance at highest frequencies stems from the contact between LFP and the aluminum foil, which likely has a thin oxide or fluoride surface layer that may impose a small electronic resistance.

The cycling data and impedance spectra of the cells containing the LP57 electrolyte with $\approx 2000 \mathrm{ppm} \mathrm{HF}$ are shown in Figure 9. Here, the specific discharge capacity at $1 \mathrm{C}$ decreases from $\approx 111 \mathrm{mAh} / \mathrm{g}_{\mathrm{LFP}}$ to $\approx 94 \mathrm{mAh} / \mathrm{g}_{\text {LFP }}$ (capacity retention of $\approx 85 \%$ ), with coulombic efficiencies increasing from $99.2 \%$ to $99.8 \%$. Thus, the graphite/LFP cell 

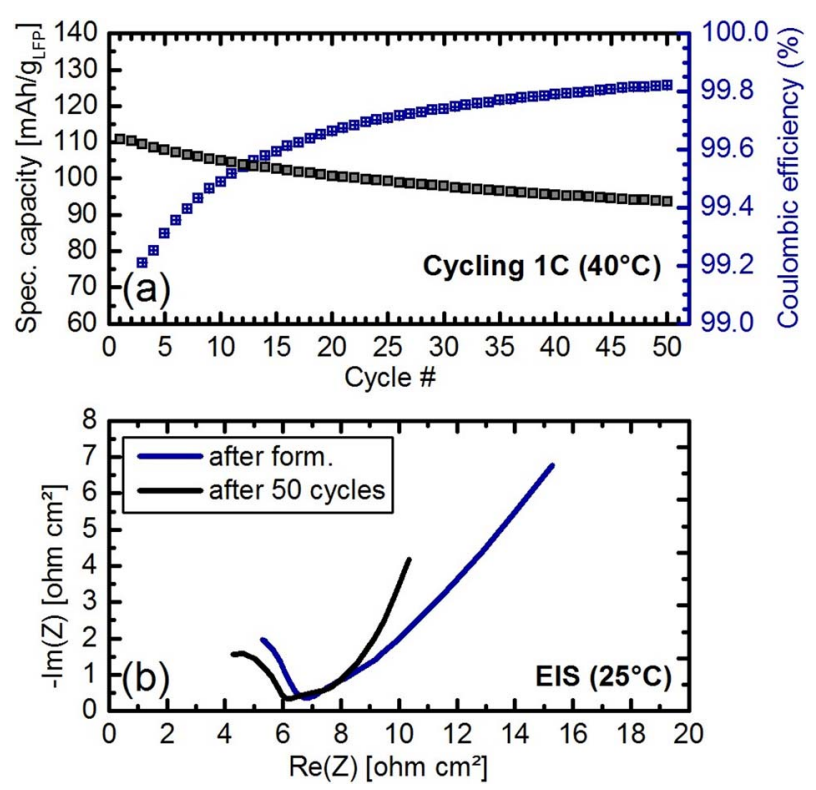

Figure 9. a) Specific discharge capacity (black symbols) and coulombic efficiency (blue symbols) of graphite/LFP cells cycled with LP57 electrolyte + $\approx 2000 \mathrm{ppm} \mathrm{HF}$ between $2.0-4.0 \mathrm{~V}$ at $1 \mathrm{C}$ and $40^{\circ} \mathrm{C}(\mathrm{CCCV}$ charge until $\mathrm{C} / 20$, and $\mathrm{CC}$ discharge). Two Formation was done at $\mathrm{C} / 10$ and $25^{\circ} \mathrm{C}$ ( 2 cycles, not shown). b) Impedance spectra of an LFP cathode measured at 50\% SOC after formation (blue line) and after 50 cycles (black line). The impedance is recorded from $100 \mathrm{kHz}$ to $100 \mathrm{mHz}$ with a perturbation of $15 \mathrm{mV}$ at $25^{\circ} \mathrm{C}$ under open circuit conditions.

containing HF-contaminated electrolyte shows a significantly lower initial discharge capacity as well as poorer coulombic efficiencies and inferior capacity retention than the graphite/LFP cell cycling with LP57 electrolyte without intentionally added HF. This could be caused by (i) reaction of parts of the HF with the lithiated graphite anode to $\mathrm{H}_{2}$ and $\mathrm{LiF},{ }^{21}$ and/or (ii) by HF-facilitated dissolution of iron from the LFP lattice, which has previously been reported by Amine et al. ${ }^{35}$ Most notably, however, the impedance spectra of the cathode in Figure 9b show a clearly pronounced semi-circle in the high-frequency region, which is present before and after cycling and remains almost constant in magnitude. The capacitance of this semi-circle is in the order of $\approx 0.5 \mu \mathrm{F} / \mathrm{cm}^{2}$, what clearly indicates the interface coating/current collector. In light of the above experiments on graphite/LNMO cells, this means that the addition of HF to a graphite/LFP cell leads to the formation of a contact resistance at the Al/LFP interface. The fact that this contact resistance does not change significantly over cycling implies either that the HF added to the electrolyte is likely being consumed directly after cell assembly or within the first few cycles (e.g., by reaction with the cell materials or by its reduction to $\mathrm{LiF}$ and $\mathrm{H}_{2}$ at the anode) $;^{21}$ it could also be due to the rather large carbon content of the compressed LFP cathode, which slows down the growth of $R_{\text {Cont. }}$ (see Figure 2). While this question cannot be resolved here, it is clear that $\mathrm{HF}$ present in the electrolyte does lead to a contact resistance at the $\mathrm{Al} /$ cathode interface due to the formation of an insulating surface film on the aluminum current collector. Since HF is most likely formed upon electrolyte oxidation in $\mathrm{PF}_{6}{ }^{-}$based electrolytes (see above discussion), Figure $9 \mathrm{~b}$ provides further evidence that the increase of $R_{\mathrm{Cont}}$. upon cycling graphite/LNMO cells at elevated temperature is a consequence of continuous electrolyte oxidation and HF formation.

These results show that the impedance increase of high-voltage cathodes is caused by electrochemical electrolyte oxidation and concomitant formation of an insulating surface film on the aluminum current collector. In graphite/LNMO cells, electrolyte oxidation and the subsequent deposition of transition metals on the anode are the main ageing phenomena at elevated temperatures. ${ }^{8}$ However, as the voltage profile is very flat, the increased overpotential (from $R_{\text {Cont. }}$ ) is not very strongly reflected in the capacity retention of graphite/LNMO cells (see Figure 4), particularly when charging is conducted in CCCV mode. However, a growing $R_{\text {Cont. }}$ will more strongly affect the energy retention and the round-trip efficiency of graphite/LNMO cells, as it increases/lowers the average charge/discharge voltage. When other high voltage cathodes are considered, as for example overlithiated manganese-rich NCMs (also referred to as HE-NCM) which operate at up to $4.7 \mathrm{~V},{ }^{36}$ an increase in the cathode impedance caused by contact resistances with the $\mathrm{Al} /$ cathode interface is expected to lead to a more significant capacity fading (and energy fading) to the steeper voltage profile.

\section{Conclusions}

The impedance of a high-voltage LNMO cathode is dominated by a high-frequency semi-circle which increases upon cycling at elevated temperatures $\left(\geq 40^{\circ} \mathrm{C}\right)$. It was shown that this impedance feature is characterized by a low interfacial capacitance, a very weak temperature-dependence, and a strong cell stack compression dependence, based on which it can be ascribed unambiguously to an electronic contact resistance at the LNMO cathode/aluminum current collector interface $\left(R_{\text {Cont. }}\right)$. By comparing LNMO cathodes coated either on aluminum or glassy carbon current collectors, it could be shown that this interfacial contact resistance is mainly caused by the formation of an insulating surface film on the aluminum current collector rather than by the corrosion of the conductive carbon in the cathode electrode. The evolution of $R_{\text {Cont }}$. upon cycling of graphite/LNMO cells with a micro-reference electrode was quantified by an impedance methodology where cathode impedance spectra are acquired under both non-blocking (10\% SOC) and blocking conditions (100\% SOC), the simultaneous fitting of which enables a straightforward deconvolution of the various resistances contributing to the overall cathode impedance.

As the literature suggests that protic species can be formed upon electrolyte oxidation at high potential, which in turn react with $\mathrm{LiPF}_{6}$ to $\mathrm{HF}$, we examined the effect of $\mathrm{HF}$ on the formation of a contact resistance in graphite/LFP cells. Indeed, adding an HF-contaminated electrolyte to a graphite/LFP cell, which operates at potentials where no electrolyte oxidation occurs, we could demonstrate that this results in the appearance of a high-frequency semi-circle corresponding to a contact resistance at the Al/LFP interface. This phenomenon will be also critical for other high-voltage cathode active materials like overlithiated manganese-rich NCM.

\section{Acknowledgment}

Financial support by the BASF SE through its Research Network on Electrochemistry and Batteries is gratefully acknowledged. M. W. acknowledges funding by the German Federal Ministry for Economic Affairs and Energy (project LiMo, grant number 03ET6045D) and J. L. acknowledges support by the German Federal Ministry of Education and Research (project ExZellTUM II, grant number 03XP0081).

\section{ORCID}

Daniel Pritzl (D) https://orcid.org/0000-0002-9029-107X

Andreas E. Bumberger (D) https://orcid.org/0000-0001-9346-4864

Morten Wetjen (D) https://orcid.org/0000-0002-2357-1151

Johannes Landesfeind (D) https://orcid.org/0000-0003-0333-2185

Sophie Solchenbach (D) https://orcid.org/0000-0001-6517-8094

\section{References}

1. V. Etacheri, R. Marom, R. Elazari, G. Salitra, and D. Aurbach, Energy Environ. Sci., 4, 3243 (2011).

2. A. H. Tkaczyk, A. Bartl, A. Amato, V. Lapkovskis, and M. Petranikova, J. Phys. D. Appl. Phys., 51 (2018)

3. C. Banza Lubaba Nkulu, L. Casas, V. Haufroid, T. De Putter, N. D. Saenen, T. Kayembe-Kitenge, P. Musa Obadia, D. Kyanika Wa Mukoma, J. M. Lunda Ilunga, T. S. Nawrot et al., Nat. Sustain., 1, 495 (2018).

4. J.-H. Kim, N. P. W. Pieczonka, and L. Yang, ChemPhysChem, 15, 1940 (2014). 
5. H. Duncan, D. Duguay, Y. Abu-Lebdeh, and I. J. Davidson, J. Electrochem. Soc., 158, A537 (2011).

6. D. Lu, M. Xu, L. Zhou, A. Garsuch, and B. L. Lucht, J. Electrochem. Soc., 160, A3138 (2013).

7. A. Bhandari and J. Bhattacharya, J. Electrochem. Soc., 164, A106 (2017).

8. N. P. W. Pieczonka, Z. Liu, P. Lu, K. L. Olson, J. Moote, B. R. Powell, and J.-H. Kim, J. Phys. Chem. C, 117, 15947 (2013).

9. K. Leitner, H. Wolf, A. Garsuch, F. F. Chesneau, and M. Schulz-Dobrick, J. Power Sources, 244, 548 (2013).

10. R. Jung, M. Metzger, F. Maglia, C. Stinner, and H. Gasteiger, J. Phys. Chem. Lett., 8, 4820 (2017).

11. R. Jung, M. Metzger, F. Maglia, C. Stinner, and H. A. Gasteiger, J. Electrochem. Soc., 164, A1361 (2017)

12. M. Metzger, B. Strehle, S. Solchenbach, and H. A. Gasteiger, J. Electrochem. Soc., 163, A798 (2016).

13. J. Cha, J. G. Han, J. Hwang, J. Cho, and N. S. Choi, J. Power Sources, 357, 97 (2017)

14. D. Aurbach, B. Markovsky, Y. Talyossef, G. Salitra, H.-J. Kim, and S. Choi, J. Power Sources, 162, 780 (2006).

15. H. Duncan, Y. Abu-Lebdeh, and I. J. Davidson, J. Electrochem. Soc., 157, A528 (2010).

16. M. Gaberscek, J. Moskon, B. Erjavec, R. Dominko, and J. Jamnik, Electrochem. Solid-State Lett., 11, A170 (2008).

17. S. Srinivasan, Fuel Cells: From Fundamentals to Applications.

18. J. Landesfeind, D. Pritzl, and H. A. Gasteiger, J. Electrochem. Soc., 164, A1773 (2017).

19. S. Solchenbach, D. Pritzl, E. J. Y. Kong, J. Landesfeind, and H. A. Gasteiger, J. Electrochem. Soc., 163, A2265 (2016).

20. D. Pritzl, J. Landesfeind, S. Solchenbach, and H. A. Gasteiger, J. Electrochem. Soc., 165, A2145 (2018).

21. D. Strmcnik, I. E. Castelli, J. G. Connell, D. Haering, M. Zorko, P. Martins, P. P. Lopes, B. Genorio, T. Østergaard, H. A. Gasteiger, F. Maglia,
B. K. Antonopoulos, V. R. Stamenkovic, J. Rossmeisl, and N. M. Markovic., Nat. Catal., 1, 255 (2018).

22. D. Pritzl, S. Solchenbach, M. Wetjen, and H. A. Gasteiger, J. Electrochem. Soc., 164, A2625 (2017)

23. M. Gaberscek, J. Moskon, B. Erjavec, R. Dominko, and J. Jamnik, Electrochem. Solid-State Lett., 11, A170 (2008).

24. N. Ogihara, S. Kawauchi, C. Okuda, Y. Itou, Y. Takeuchi, and Y. Ukyo, J. Electrochem. Soc., 159, A1034 (2012).

25. J. Landesfeind, J. Hattendorff, A. Ehrl, W. A. Wall, and H. A. Gasteiger, J. Electrochem. Soc., 163, A1373 (2016).

26. J. W. Braithwaite, A. Gonzales, G. Nagasubramanian, S. J. Lucero, D. E. Peebles, J. A. Ohlhausen, and W. R. Cieslak, J. Electrochem. Soc., 146, 448 (1999).

27. K. Kanamura, T. Umegaki, S. Shiraishi, M. Ohashi, and Z. Takehara, J. Electrochem. Soc., 149, A185 (2002).

28. X. Zhang and T. M. Devine, J. Electrochem. Soc., 153, B375 (2006).

29. X. Zhang, B. Winget, M. Doeff, J. W. Evans, and T. M. Devine, J. Electrochem. Soc., 152, B448 (2005).

30. T. Ma, G. L. Xu, Y. Li, L. Wang, X. He, J. Zheng, J. Liu, M. H. Engelhard, P. Zapol, L. A. Curtiss, J. Jorne, K. Amine, and Z. Chen, J. Phys. Chem. Lett., 8, 1072 (2017).

31. S. S. Zhang, K. Xu, and T. R. Jow, J. Electrochem. Soc., 149, A586 (2002).

32. S. Solchenbach, M. Metzger, M. Egawa, H. Beyer, and H. A. Gasteiger, J. Electrochem. Soc., 165, A3022 (2018).

33. D. Aurbach, A. Zaban, Y. Ein-Eli, I. Weissman, O. Chusid, B. Markovsky, M. Levi, E. Levi, A. Schechter, and E. Granot, J. Power Sources, 68, 91 (1997).

34. T. Kawamura, A. Kimura, M. Egashira, S. Okada, and J. I. Yamaki, J. Power Sources, 104, 260 (2002).

35. K. Amine, J. Liu, and I. Belharouak, Electrochem. commun., 7, 669 (2005).

36. M. M. Thackeray, S.-H. Kang, C. S. Johnson, J. T. Vaughey, R. Benedek, and S. A. Hackney, J. Mater. Chem., 17, 3112 (2007). 